KRONIKA

STUDIA NORWIDIANA 37:2019

DOI: http://dx.doi.org/10.18290/sn.2019.37-16

JÓZEF FRANCISZEK FERT

\title{
25 LAT FUNDACJI NORWIDOWSKIEJ
}

15 września 1992 r. Sąd Rejonowy dla miasta stołecznego Warszawy, Wydział XVI Gospodarczo-Rejestracyjny wpisał naszą organizację do Rejestru Fundacji; tak więc w bieżącym roku mija ćwierć wieku od powstania tej - jak później potwierdzono - organizacji pożytku publicznego, uprawnionej m.in. do przyjmowania jednoprocentowego odpisu od podatku od osób fizycznych i innych darowizn oraz zobowiązanej do gospodarowania posiadanymi środkami na rzecz wspierania rozwoju działalności naukowej i popularyzacyjnej, skupionej na „zjawisku Norwid”. Działalność Fundacji Norwidowskiej ${ }^{1}$ określa statut przyjęty przez właściwy sąd rejestrowy.

Założycielem, a zarazem fundatorem i pierwszym prezesem FN jest prof. Stefan Sawicki, który kierował fundacją ponad 20 lat. Od 2014 r. funkcję prezesa objął piszący te słowa, który od początku uczestniczył w zarządzie fundacji początkowo jako sekretarz, a następnie jako wiceprezes. Kadencja prezesa i zarządu fundacji trwa 3 lata. Prezesa i zarząd powołuje na kolejne kadencje Fundator, czyli prof. Stefan Sawicki. Statut może określić inny sposób powoływania zarządu, a mianowicie powierzyć tę prerogatywę komisji rewizyjnej.

Obecny zarząd FN stanowią: dr Edyta Chlebowska (wiceprezes), dr Łukasz Niewczas (sekretarz), dr hab. Anna Kozłowska prof. UKSW (członek zarządu) i dr hab. Włodzimierz Toruń (członek zarządu). Członkowie zarządu i prezes pełnią swoje funkcje honorowo, podobnie jak członkowie komisji rewizyjnej, której przewodniczył zmarły w roku 2017 Andrzej Paluchowski.

Czego fundacja dokonała przez ubiegające dwadzieścia pięć lat istnienia? Należy po pierwsze stwierdzić, że działała zgodnie ze swym powołaniem i prawami zapisanymi w statucie. Jest to naprawdę ważne, bowiem co roku FN zobowiązana jest do przedkładania stosownych sprawozdań z działalności odpowiednim organom państwowego nadzoru nad fundacjami, a szczególnie nad tymi, które

\footnotetext{
${ }^{1}$ Dalej nazwę podaję za pomocą skrótu: FN.
} 
posiadają status organizacji pożytku publicznego. Co roku też odbywa się zebranie zarządu, na którym przeprowadza on analizę działalności oraz dyskutuje nad bliższymi i dalszymi planami pracy. Doroczną ocenę pracy fundacji wystawia również komisja rewizyjna, od której zależy wniosek o udzielenie zarządowi absolutorium.

Po drugie - to, co chyba najważniejsze i najbardziej rozwinięte - FN wspiera działalność naukową i popularyzacyjną związaną z życiem i twórczością Cypriana Norwida. Tu naprawdę, mimo że nie jest krociowym posiadaczem, ma się czym pochwalić. Od początku wspiera finansowo prace naukowe w statutowym zakresie, szczególnie młodych i/lub debiutujących uczonych poprzez udzielanie subsydiów na cele badawcze i/lub wspieranie publikacji naukowych, przygotowywanych w efekcie tych prac. FN wsparła m.in. kilka publikacji, które ukazały się jako książki w serii „Studia i Monografie” (uprzednio: „Studia Norwidiana. Biblioteka"), którą wydaje Towarzystwo Naukowe KUL oraz Ośrodek Badań nad Twórczością Cypriana Norwida KUL ${ }^{2}$. Dzięki pomocy FN wydrukowany został m.in. tom cennych studiów Elżbiety Feliksiak, Poezja i myśl. Studia o Norwidzie (Lublin 2001).

W tej perspektywie mieści się także, a może nawet przede wszystkim, wspieranie corocznej inicjatywy wydawniczej o nazwie „Studia Norwidiana”, czasopisma ze wszech miar skoncentrowanego na zjawisku, którego imię nosi patron fundacji ${ }^{3}$. Od momentu powstania, czyli od 1992 r., do dziś FN ma swój udział w przygotowaniu i naukowym opracowaniu materiałów stanowiących istotny składnik tego „organu norwidystyki” krajowej i światowej. Ten wyrazisty wkład to wsparcie finansowe dotyczące procesu przedwydawniczego opiniowania każdego tekstu planowanego do zamieszczenia w piśmie, a przede wszystkim finansowanie bieżącej bibliografii adnotowanej, która ukazuje się od początku istnie-

\footnotetext{
${ }^{2}$ Lubelski Ośrodek Norwidowski nosił uprzednio nazwę Międzywydziałowy Zakład Badań nad Twórczością Cypriana Norwida, następnie - Instytut Badań nad Twórczością Cypriana Norwida, a obecnie - Ośrodek Badań nad Twórczością Cypriana Norwida, który działa w ramach Wydziału Nauk Humanistycznych Katolickiego Uniwersytetu Lubelskiego Jana Pawła II.

${ }^{3} \mathrm{~W}$ pierwszym numerze pisma, w słowie od redakcji czytamy m.in.: ,Studia Norwidiana są rocznikiem poświęconym twórczości i życiu jednego pisarza. Towarzystwo Naukowe Katolickiego Uniwersytetu Lubelskiego, rozpoczynając wydawanie pisma w r. 1983, chce w ten sposób uczcić setną rocznicę śmierci Cypriana Norwida [...]. Chcielibyśmy, aby pismo przyczyniło się do pogłębienia znajomości jednego z największych, lecz i najtrudniejszych polskich pisarzy [...], aby stało się organem własnym wszystkich norwidologów”. Do roku 2017 ukazało się 35 numerów pisma o łącznej objętości blisko 500 arkuszy wydawniczych. „Studia Norwidiana" znalazły się na międzynarodowej liście czasopism naukowych, a od roku 2017 ukazują się w sieci internetowej w wersji anglojęzycznej.
} 
nia rocznika dzięki wyspecjalizowanym pracownikom naukowym bibliografistyki; dział bibliograficzny pod nazwą Norwidiana prowadziła najpierw Anna Polakowska (bibliografia za lata 1981-1989), kontynuuje tę pracę Aleksandra Żurawska-Włoszczyńska; prócz tego czasopismo zamieszcza obszerne bloki bibliograficzne, skupione na wybranych dziedzinach piśmiennictwa, np. bibliografia norwidianów niemieckojęzycznych (Wojciech Kudyba) czy bibliografia przekładów pism Norwida na język angielski (Agata Brajerska-Mazur).

Inną, ważną działalnością FN jest wspieranie cyklicznej międzynarodowej sesji naukowej pod nazwą „Colloquia Norwidiana”, która organizowana jest niezmiennie co dwa lata przez lubelski (kulowski) ośrodek norwidystyczny. Sesje odbywają się na ogół w Kazimierzu Dolnym, ale zdarzały się też wspaniałe wyprawy naukowe śladami fascynacji artystycznych i intelektualnych poety: do Rzymu - tropami Quidama; do Toskanii - po górach i dolinach niepowtarzalnego włoskiego piękna, które tak fascynowało Norwida... Każda sesja przynosi owoce mądrości i wrażliwości literackiej jej uczestników w postaci studiów, które zasilają łamy „Norwidianów”. We wszystkich tych przedsięwzięciach partycypuje materialnie i logistycznie nasza fundacja.

Na koniec tego ,akapitu” to, co jest bodaj najbardziej widoczne w działalności FN - wyróżnianie najwybitniejszych i najbardziej zasłużonych twórców i mecenasów kultury (w tym także instytucji) w kraju i za granicą medalem ustanowionym dla wyrażenia wdzięczności - mówiąc słowami poety: „Współczesnym zacnym oddać cześć, / To jakby cześć Bożej prawicy..." (Do emira Abd el Kadera w Damaszku) - tym wszystkim, którzy służą pomnażaniu pamięci i wiedzy o naszym poecie.

W ciągu kilkunastu lat, od 2001 do 2017 r., fundacja przyznała ów medal piękną rzeźbę medalierską p. Anny Beaty Wątróbskiej-Wdowiarskiej - osiemnastu osobom. O przyjęcie pierwszego medalu - poprosiliśmy najsławniejszego „popularyzatora” Norwidowskiej myśli Jego Świątobliwość Jana Pawła II. Uroczystość wręczenia medalu wdzięczności miała miejsce na Watykanie wiosną $2001 \mathrm{r}$.

Następnie nasz medal trafiał w ręce wybranych przez fundację, zasłużonych dla popularyzacji Norwida i/lub budujących jego mądrą legendę w kraju i za granicą uczonych i mecenasów kultury. I tak w roku 2001 medal otrzymał kard. Stanisław Dziwisz, w tym samym 2001 r. medal przyjęła znakomita propagatorka wielkości Norwida, wychowawczyni wielu pokoleń polonistów - prof. Irena Sławińska. W roku 2002 medal otrzymał Władysław Bartkiewicz - wierny sojusznik i sponsor naszej fundacji, w tymże roku medal wręczaliśmy niezwykłemu człowiekowi i naszemu oddanemu sprzymierzeńcowi - abp. Alfonsowi Nossolowi. I jeszcze jeden laur w tymże 2002 r. - dla naszego dobroczyńcy Zenona 
Sroczyńskiego. W roku 2003 medal trafił do rąk Małgorzaty Niemenowej jako wyraz uznania dla jej śp. męża Czesława za niezwykłe współbrzmienie jego sztuki muzycznej z poezją autora Bema pamięci żałobnego-rapsodu... W roku 2003 uhonorowaliśmy w Lublinie - w Muzeum Literackim im. Józefa Czechowicza - Adama Czerniawskiego, mieszkającego w Anglii, znakomitego tłumacza poezji Norwida na język angielski, a w roku 2006 medal otrzymała jedna z najwybitniejszych znawczyń twórczości poety - prof. Zofia Stefanowska. W $2008 \mathrm{r}$. wyróżniliśmy prof. Jadwigę Puzyninę, wybitną językoznawczynię, twórczynię i kierowniczkę warszawskiej Pracowni Słownika Języka Cypriana Norwida. W roku 2009 medal otrzymał zasłużony Ośrodek Kultury im. Cypriana Norwida w Krakowie, a w następnym roku uczciliśmy medalem prof. Zofię Trojanowiczową, wybitną badaczkę polskiego romantyzmu, założycielkę pracowni Kalendarza Życia i Twórczości Norwida w Poznaniu; nieoceniony Kalendarz Norwidowski został ukończony i wydany drukiem. W 2011 r. medal otrzymał Edward Kawęcki, wieloletni dyrektor Liceum im. Cypriana Norwida w Krasnymstawie, inicjator i organizator dorocznego ogólnopolskiego konkursu wiedzy o poecie dla uczniów szkół średnich. W 2012 r. medal otrzymał znakomity komentator twórczości Norwida - prof. Zdzisław Łapiński, a w roku następnym - Krzysztof Jeżewski, mieszkający we Francji thumacz poezji Norwida na język francuski i popularyzator jego twórczości na zachodzie Europy. W roku 2015 fundacja uhonorowała swym najważniejszym wyróżnieniem prof. Stefana Sawickiego organizatora lubelskiej szkoły norwidologicznej. W 2016 r. medal otrzymał prof. Mieczysław Inglot, badacz i popularyzator twórczości Norwida, a w roku 2017 prof. Rolf Fieguth, pierwszy thumacz Vade-mecum na język niemiecki, komentator Quidama, slawista i popularyzator literatury słowiańskiej na Zachodzie, mieszkający na stałe w Szwajcarii.

Uroczystość wręczenia prof. Rolfowi Fieguthowi Medalu za Zasługi w Upowszechnianiu Twórczości Norwida odbyła się 17 października 2017 r. w auli muzycznej Collegium Jana Pawła II i zgromadziła zarówno przedstawicieli tutejszej polonistyki, jak i innych miłośników Norwida, także spoza Lublina. Laudację wygłosiła prof. Mirosława Hanusiewicz-Lavallee; laureat wystąpił z wykładem: Chrześcijaństwo dla wszystkich - garść uwag o „Quidamie” Norwida. Krótkie, syntetyczne wystąpienie Fiegutha skupione było na kwestii obrazowania i znaczenia czasu w poemacie, podkreśliło znamienną dla poety koncepcję współ-c z e s n o ś c i, czyli swoistego symultanizmu temporalnego, niejako współbrzmiącego z jego gnomicznym określeniem czasu w wierszu Przeszłość: 
Nie Bóg stworzył przeszłość i śmierć, i cierpienia, Lecz ów, co prawa rwie,

$[\ldots]$

Przeszłość jest i dziś, i te dziś daléj ${ }^{4}$.

$\mathrm{Z}$ nadzieją na dalsze dobre inicjatywy w norwidowskiej konfraterni składamy Fundacji Norwidowskiej jubileuszowe gratulacje i życzenia znaczących osiągnięć na niwie kultury narodowej i europejskiej. A naszym potencjalnym dobroczyńcom podajemy numer, na który można składać darowizny na rzecz Fundacji Norwidowskiej: KRS 0000129753.

${ }^{4}$ C. Norwid, Vade-mecum, oprac. J. Fert, Lublin 2004, s. 15. W powszechnym odbiorze utrwaliła się porzucona przez poetę wersja, którą przyjął Z Przesmycki: „Przeszłość, jest to dziś, tylko cokolwiek daléj” - C. Norwid, Reszta wierszy odszukanych po dziś, a dotąd nie drukowanych, zebrał i wydał Z. Przesmycki, Warszawa 1933, s. 33. 